\title{
CONSTRICTION RATE VARIATION PRODUCED BY PARTIAL LIGATION OF THE PORTAL VEIN AT PRE-HEPATIC PORTAL HYPERTENSION INDUCED IN RATS
}

Variação da taxa de constrição produzida pela ligadura parcial da veia porta na hipertensão portal pré-hepática induzida em ratos

\author{
Daren Athiê Boy RODRIGUES, Aline Riquena da SILVA, Leonardo Carvalho SERIGIOLLE, \\ Ramiro de Sousa FIDALGO, Sergio San Gregorio FAVERO, Pedro Luiz Squilacci LEME
}

Trabalho realizado no Laboratório de Habilidades Cirúrgicas Avançadas da Universidade Nove de Julho, São Paulo, SP, Brasil.

HEADINGS - Hypertension, portal. Ligation. Portal vein. Portal system. Models, animal.
ABSTRACT - Background: Partial portal vein ligation causes an increase in portal pressure that remains stable even after the appearance of collateral circulation, with functional adaptation to prolonged decrease in portal blood flow. Aim: To assess whether different constriction rates produced by partial ligation of the vein interfere with the results of this experimental model in rats. Methods: Three groups of five rats each were used; in group 1 (sham-operated), dissection and measurement of portal vein diameters were performed. Portal hypertension was induced by partial portal vein ligation, reducing its size to $0.9 \mathrm{~mm}$ in the remaining 10 animals, regardless of the initial diameter of the veins. Five animals with portal hypertension (group 2) underwent reoperation after 15 days and the rats in group 3 after 30 days. The calculation of the constriction rate was performed using a specific mathematical formula $\left(1-\pi r^{2} / \pi R^{2}\right) x$ $100 \%$ and the statistical analysis with the Student $t$ test. Results: The initial diameter of the animal's portal vein was $2.06 \mathrm{~mm}$, with an average constriction rate of the $55.88 \%$; although the diameter of the veins and the constriction rate in group 2 were lower than in group $3(2.06 \mathrm{~mm}$ $-55,25 \%$ and $2.08 \mathrm{~mm}-56.51 \%$, respectively), portal hypertension was induced in all rats and no significant macroscopic differences were found between the animals that were reoperated after 15 days and after 30 days respectively, being the shorter period considered enough for the evaluation. Comparing the initial diameter of the vein and the rate of constriction performed in groups 2 and 3, no statistic significance was found $(p>0.05)$. Conclusion: Prehepatic portal hypertension in rat can be induced by the reduction of the portal vein diameter to $0.9 \mathrm{~mm}$, regardless the initial diameter of the vein and the vessel constriction rate.

\section{Correspondence:}

Pedro Luiz Squilacci Leme

e-mail: gorableme@uol.com.br

Financial source: none

Conflicts of interest: none

Received for publication: 06/05/2014 Accepted for publication: 12/08/2014 DESCRTORES - Hipertensão portal.
Ligadura. Veia porta. Sistema porta. Modelos animais.
RESUMO - Racional: A ligadura parcial da veia porta acarreta aumento da pressão portal que se mantém estável mesmo após o aparecimento da circulação colateral, havendo adaptação funcional à diminuição prolongada do fluxo sanguíneo hepático. Objetivo: Avaliar se diferentes taxas de constrição produzidas por esta ligadura interferem em modelo experimental no rato. Métodos: Foram utilizados três grupos de cinco animais; no grupo 1 (sham-operated) foi realizada dissecção e medida do diâmetro da veia porta. A hipertensão portal foi induzida pela ligadura parcial da veia porta, reduzindo seu calibre para $0,9 \mathrm{~mm}$ nos 10 animais restantes, independente do diâmetro inicial das veias. Cinco animais com hipertensão portal (grupo 2) foram reoperados após 15 dias e os ratos do grupo 3 após 30 dias. O cálculo da taxa de constrição foi realizado através de fórmula matemática específica $\left(1-\pi r^{2} / \pi R^{2}\right) \times 100 \%$ e a análise estatística com o teste $t$ de Student. Resultados: 0 diâmetro médio inicial da veia porta dos animais foi de $2,06 \mathrm{~mm}$, com taxa de constrição média de 55,88\%; embora o diâmetro das veias e a taxa de constrição no grupo 2 tenha sido menor que no grupo $3(2,06 \mathrm{~mm}-55,25 \%$ e $2,08 \mathrm{~mm}-56,51 \%$ respectivamente), em todos conseguiu-se induzir hipertensão portal e não foram encontradas diferenças macroscópicas significativas entre os animais reoperados após 15 ou 30 dias, sendo considerado o prazo menor suficiente para avaliação. Quando comparados o diâmetro inicial da veia e a taxa de constrição realizadas nos grupos 2 e 3 não houve significância estatística $(p>0,05)$. Conclusão: A hipertensão portal pré-hepática no rato pode ser induzida pela redução de calibre da veia porta para $0,9 \mathrm{~mm}$ de diâmetro, independente do diâmetro inicial da veia e da taxa de constrição a que este vaso foi submetido.

INTRODUCTION

I n the portal hypertension dilation of the splanchnic veins occurs, and collateral circulation is developed. This situation may happen with diseases in pre, intra or post-hepatics stages ${ }^{10}$. Thrombosis of the portal vein or splenic vein triggers pre-hepatic portal hypertension. The hepatic causes can be divided into pre-sinusoidal (schistosomiasis and congenital hepatic fibrosis); sinusoidal (cirrhosis, alcoholic hepatitis, nodular regenerative hyperplasia and polycystic liver); or post-sinusoidal (sinusoidal obstructive syndrome and Budd-Chiari syndrome). The post-hepatic may be due to thrombosis of the inferior cava vein, as well as cardiac causes (restrictive cardiomyopathy, constrictive pericarditis and congestive heart failure), or even pulmonary hypertension ${ }^{1}$. In order to reduce the venous pressure in this system, dilated and tortuous veins appear, as well as the release of vasoactive substances by the endothelium, which act on the vessels ${ }^{10}$, 
and angiogenesis that also contributes to the decompression of the portal circulation ${ }^{1}$.

The portal pressure in rodents can be measured in millimeters of mercury ${ }^{10}(\mathrm{mmHg})$ or centimeters of water ${ }^{2}$. Yokoyama et al. ${ }^{16}$, evaluating this pressure in $\mathrm{mm} \mathrm{Hg}$, found portal pressures close to $5 \mathrm{mmHg}$ in the control group, and when they performed the portal vein partial ligature this pressure rose to approximately $13 \mathrm{mmHg}$.

The experimental model with the partial portal vein ligature does not compromise the hepatic function significantly ${ }^{10,14}$, leading to a peak of pressure in the first $24 \mathrm{~h}$, which stabilizes twice as much the initial values after 15 days, with the dilation of the splanchnic vessels, keeping itself stable even after the appearance of this collateral circulation ${ }^{14}$ with the posterior adaptation to the prolonged decrease of the blood flow through the portal vein ${ }^{13,16}$.

The effects of the persistent decrease in the blood supply, such as it occurs in this model of decrease on portal vein caliber, have still been studied, with the assumption that structural and functional hepatic changes happen in the mesentery vessels and the abdominal cavity, as well as angiogenesis and adaptations of the microcirculation. The neovascularization that appears near to the hepatic artery acquires similar characteristics to arterioles, becoming compensation via to the liver blood supply. Yokoyama et al. ${ }^{16}$ confirmed that angiogenesis comes out when there is hypoxia, possibly a crucial factor in this experimental model, but that can also accompany the inflammatory processes and oxidative stress.

The aim of this study was to evaluate whether the initial caliber of the rat's portal vein interferes in the appearance of the pre-hepatic portal hypertension induced by the reduction of its caliber to a single diameter in all animals.

\section{METHODS}

This experiment was carried out at the Laboratory of Advanced Surgical Skills at Universidade Nove de Julho, São Paulo, SP, Brazil. The general rules for experimental research at the institution are strictly supervised and follow specific protocols ${ }^{13}$, being conducted after being approved by the Ethics Committee on Animal Use of the University (protocol 0040 / 2012).

A total of 15 animals (Rattus norvegicus albinus), Wistar, female, young adult, weighing 250-300 g on average, were divided into three groups of five animals each, and classified according to type of surgery and time to reoperation. Thus, three groups were obtained: group 1 (sham-operated), used as control, and two other groups where pre-hepatic portal hypertension was induced by reduction of portal vein caliber. Five animals were reoperated after 15 days, group 2 (Figure 1), and another five after 30 days, group 3, as recommended by Riquena da Silva et al. ${ }^{13}$

Before and after the completion of the operative procedures, the animals were kept in individual cages with access to water and standardized ration ad libitum, at 25 ${ }^{\circ} \mathrm{C}$, cycles of light and dark every $12 \mathrm{~h}$. Prior to operative procedures the animals were weighed.

The rats were anesthetized with intraperitoneal injection of ketamine $(50 \mathrm{mg} / \mathrm{kg})$ and xylazine $(10 \mathrm{mg} / \mathrm{kg})$. Laparotomy was performed and the hepatic hilum exposed. Portal vein was dissected near the confluence of the superior mesenteric vein and splenic vein and its diameter was measured with a caliper rule (Figure $1 \mathrm{~A}$ and $1 \mathrm{C}$ ). In the control group (shamoperated), the procedure was terminated at this stage and the anterior abdominal wall sutured in layers with 4-0 nylon. The rats remained in the vivarium for 15 days, when a second operation was performed to evaluate the aspect of the abdominal viscera, which did not evidence changes.
In group 2 (15 days) and group 3 (30 days), partial ligation of dissected portal vein was performed at the first operation with silk thread for ophthalmic use numbers 6-0 (Figure 1B). Such partial ligation was possible by means of a fluoretilenpropilen catheter $22 \mathrm{G}$ (Jelco $\left.{ }^{\circledR}\right)$, which has an internal diameter of $0.9 \mathrm{~mm}$ (Figure 1D and 1E). With the silk thread, partial ligature of vein was performed and the catheter was removed, allowing the reduction of the venous flow to the liver.
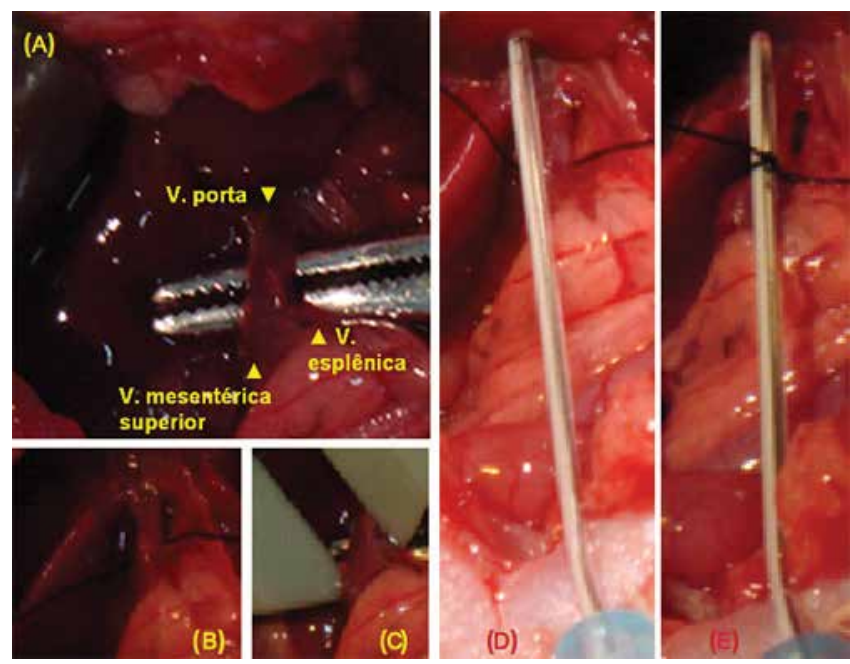

FIGURE 1 - A e B) Dissection of the hepatic hilum performed in the three groups of animals; $C$ ) assessment of the portal vein diameter with a caliper rule; $D$ and E) affixing the fluoretilenpropilen $22 \mathrm{G}$ catheter $\left(\right.$ Jelco $\left.{ }^{\circledR}\right)$ with a $0.9 \mathrm{~mm}$ internal diameter and a transverse portal vein ligature with 6-0 silk thread on the catheter

After removal of the catheter, the efficacy of partial ligation of the vein was confirmed by observing the increase in the diameter of the vessel prior to ligation (Figures 2 and 3). The abdominal wall was sutured as described above and the animals returned to the vivarium, where group 2 remained for 15 days and group 3 for 30 days, when they were reoperated.

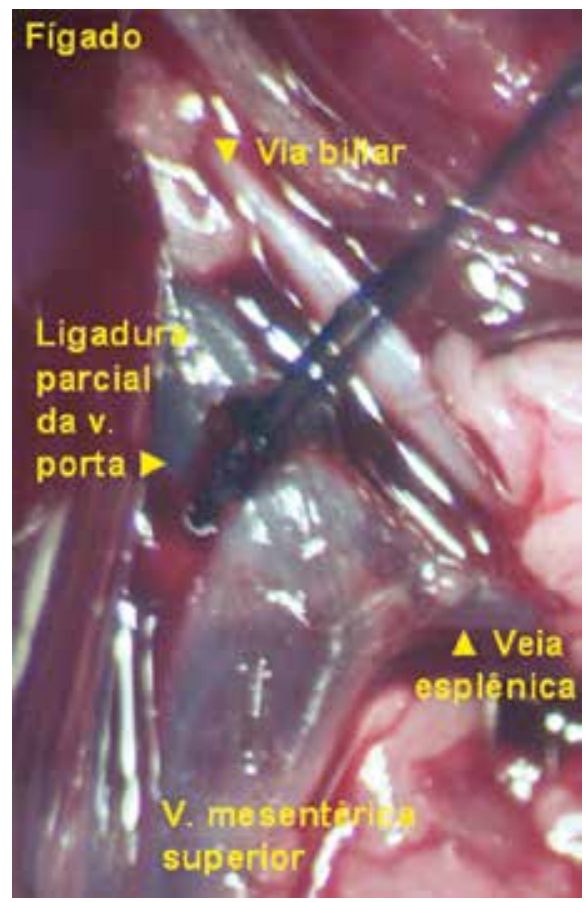

FIGURE 2 - Partial ligature with constriction of the portal vein (image made with a surgical microscope) 

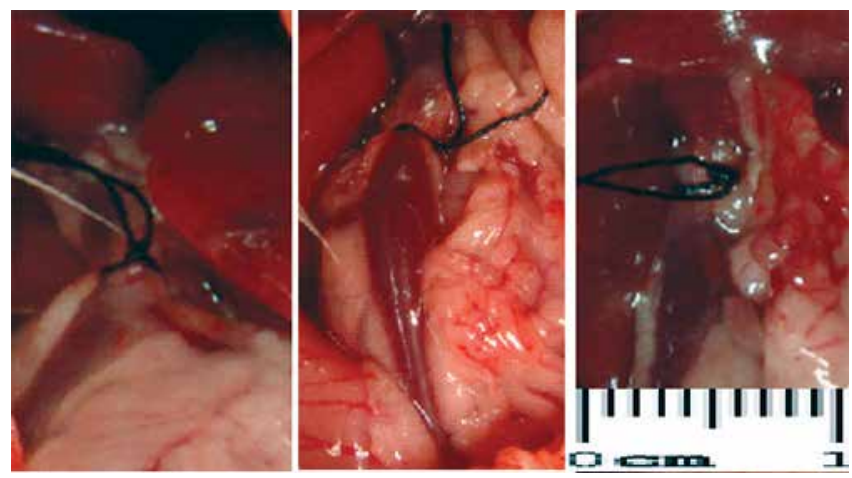

FIGURE 3 - Aspects of different rates of portal vein constriction of the animals: the diameter of the ligature was set at $0.9 \mathrm{~mm}$, regardless of the initial diameter of the portal vein of each animal in groups 2 and 3 .

After these periods of 15 or 30 days, all rats were weighed, anesthetized and underwent surgery to assess macroscopic changes of the abdominal organs (Figures 4 and 5).

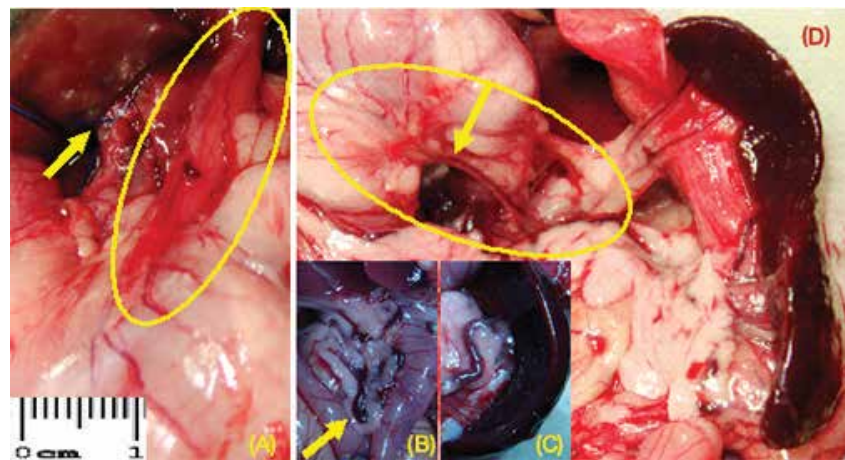

FIGURE4-A) Portal hypertension induced by the partial ligature of the portal vein (arrow) and vasodilatation of the esophagogastric junction - highlighted; $B)$ venous congestion in the territory of the superior mesenteric vein - arrow; C) splenic vein dilatation and tortuosity; D) folded posterior wall of the stomach (highlighted) and dilation of the left gastric vein (arrow), congestion of the splenic hilum vessels, and splenomegaly (animals of group 2)
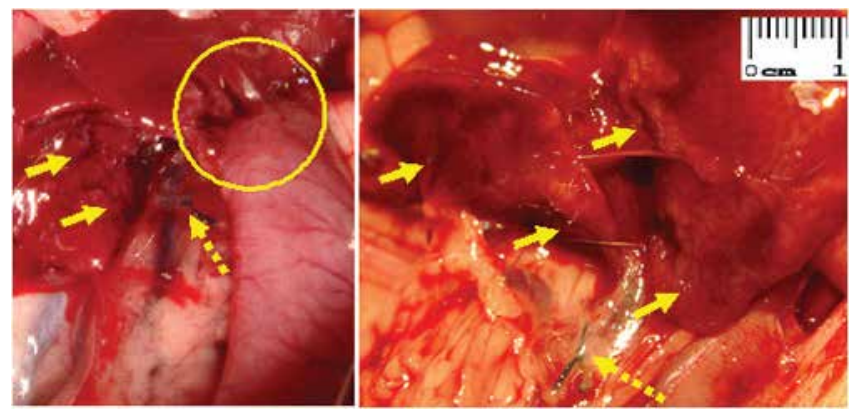

FIGURE 5 - Adherences (highlighted) and neovascularization (arrows) in the hepatic hilum of group 2 animals (reoperated after 15 days); the broken arrows show the portal vein partial ligature performed in the first operation

The measurement of portal vein below the ligature made in the first operation was performed; the portal vein was cut above the ligature for evidence of blood flow, demonstrating the absence of its complete obstruction. The evaluation of the reduction percentage in the diameter of the portal vein was done with mathematical formula that defines the rate of the vessel constriction $\left.\left(1-\pi r^{2} / \pi R^{2}\right) \times 100 \%\right)$, where the smallest radius $(r)$ corresponds to the catheter and the largest (R) to the animal's portal vein ${ }^{13,14}$.

For each animal subgroup arithmetic mean was calculated, and results later compared through statistical analysis by Student's test, being considering significant $p<0.05$. This procedure aimed to prove that even with different constricted rates of the rat's portal vein, a diameter of $0.9 \mathrm{~mm}$ is sufficient to develop portal hypertension without excessive mortality in the animals observed for 15 or 30 days. These differences didn't show to be statistically significant

The calculations of preoperative and postoperative spleen volume were presented by Riquena da Silva et al. ${ }^{13}$ in 2013. The abdominal esophagus, the stomach, the liver and the spleen of each rat were harvested and preserved for 24 $\mathrm{h}$ in a solution of $10 \%$ formalin, and then dehydrated with ethanol for posterior histological analysis.

\section{RESULTS}

The initial diameter of the animals' portal vein where portal hypertension was induced was $2.06 \mathrm{~mm}(1.6 \mathrm{~mm}$ to $2.5 \mathrm{~mm}$ ), with an average rate of vein constriction of $55.88 \%$ (43.75\% to $64 \%$ ). Although the initial diameter of the portal vein in the animals of group 2 was on average of $2.06 \mathrm{~mm}$ (constriction rate of $55.25 \%$ ) and $2.08 \mathrm{~mm}$ (constriction rate of $56.51 \%$ ) in group 3 (Table 1), it was managed to induce portal hypertension in all rats.

No significant macroscopic differences were found among the animals that were reoperated after 15 days (group 2 ) or after 30 days (group 3), and the $15^{\text {th }}$ day was considered enough for the evaluation on the impact of partial portal vein ligature. When the initial diameter of the vein and the rate of constriction performed in group 2 with the ones in group 3 were compared, these numbers were not statistically significant $(p>0.05)$.

TABLE 1 - Initial diameter of the portal vein $(\mathrm{mm})$ and the vein constriction rate (\%) achieved by reducing the diameter to $0.9 \mathrm{~mm}$

\begin{tabular}{|c|c|c|}
\hline $\begin{array}{c}\text { Animal groups } \\
\text { (reoperation) }\end{array}$ & $\begin{array}{c}\text { Initial diameter of the } \\
\text { portal vein }(\mathrm{mm})\end{array}$ & $\begin{array}{c}\text { Vein constriction } \\
\text { rate }(\%)\end{array}$ \\
\hline \multirow{2}{*}{2 (15 days) } & 2,5 & 64,0 \\
& 2,0 & 55,0 \\
& 1,9 & 52,63 \\
\hline \multirow{3}{*}{ (30 days) } & 2,3 & 60,87 \\
& 1,6 & 43,75 \\
\hline & 1,9 & 52,63 \\
\hline Mean value & 2,2 & 59,09 \\
\hline
\end{tabular}

\section{DISCUSSION}

The experimental model of partial ligature of the rats' portal vein was developed by Sikuler et al. in $1985^{12}$. The clinical correlation of the importance of these studies can be done with a lower age range patients, considering that most of the cases of portal hypertension in children are due to portal vein thrombosis, often a result of manipulation, for therapeutic purposes in the neonatal period, on the vessels of the umbilical cord ${ }^{5}$; the diameter of the portal vein in humans can be assessed with ultrasound and Doppler effect ${ }^{15}$.

Wen et al. ${ }^{14}$ estimated a deviation of approximately 
$95 \%$ of the portal blood flow when the partial ligature of the rat's portal vein is performed, with venous dilations in the mesenteric vein appearing two weeks after this ligature. This paper found significant dilatation of the superior mesenteric vein and its tributaries, both two and four weeks after the constriction of the portal vein diameter, as well as numerous dilated, congested and tortuous vessels were observed throughout the peritoneal cavity, mesentery, omentum and abdominal wall of studied animals.

The increased portal pressure can be obtained by the partial constriction of the vessel and the increased resistance to blood flow in the portal vein ${ }^{13}$. Considering an average diameter of $2 \mathrm{~mm}$ in the portal vein of the studied animals - a value close to that was described in the literature ${ }^{14}$-, and with the diameter of $0.9 \mathrm{~mm} 22 \mathrm{G}$ fluoretilenpropilen catheter used in this experiment, was possible to use the mathematical formula that defines the vein constriction rate $\left(1-r^{2} \pi / \pi R^{2}\right)$ $x 100 \%{ }^{4}$. For this vein diameter $(2 \mathrm{~mm})$, with this catheter, was able to reduce $55 \%$ on average the portal vein internal diameter, a reduction that produces an immediate increase in portal pressure estimated at four times the base value, such pressure stabilizes itself after two weeks in approximately twice the basal value and remains stable even in the period which it has already developed the dilation of the tributary ones. When catheters with a $1 \mathrm{~mm}$ diameter are used, the animal mortality is low, but the portal pressure alterations are small and do not properly contribute to the experimental mode ${ }^{14}$. In only one of the animals, in group 2 , which had the smallest diameter of all the veins evaluated $(1.6 \mathrm{~mm})$, the constriction was lower than $50 \%$ of the diameter (43.75\%), but even with this constriction rate the portal hypertension could be detected after 15 days of the initial operation.

The percentage of volume reduction of the portal vein is important, since its complete ligature prevents the animal from surviving ${ }^{14}$. This study showed an acceptable mortality and even knowing that the complete obstruction would be incompatible with survival, was evaluated whether the vein was pervious in reoperation, counting on a possible thrombosis after the establishment of collateral circulation. All the animals that completed the study period had an adequate portal blood flow. Wen et al. ${ }^{14}$, using a $0.7 \mathrm{~mm}$ diameter catheter $(24 \mathrm{G})$ reached a mortality rate of $80 \%$. When smaller diameters were used, all rats died. The mortality rate dropped between 20 and $30 \%$ when $0.8 \mathrm{~mm}$ (21G) catheters were used, corresponding to an approximate decrease on the diameter of the vein of about $88.9 \%$. In this study, with a $0.9 \mathrm{~mm}$ catheter (22G) and an approximate reduction of $55 \%$ on the portal vein, were obtained satisfactory results.

Concerning the technique of the partial portal vein ligature, there are also some options described ${ }^{6}$. Fabián et al. ${ }^{4}$ and Méndez-López et al. ${ }^{8}$, described a tactic to increase the constriction of this vein, and thus the initial resistance to blood flow, which uses three equidistant ligatures, considering this option more effective than a single ligature, enhancing the development of the collateral circulation. The use of an aneroid constrictor was also described ${ }^{3,14}$. This study showed that a single ligature is effective and can be applied close to the hepatic hilum, above the confluence of the superior mesenteric vein with the splenic vein. The single ligature in this experiment succeeded in developing an exuberant collateral circulation. During the pilot project, was used an aneroid constrictor made from a fragment of a $22 \mathrm{G}$ catheter, used to involve the portal vein and provide support to the knot, but such option proved technically difficult and unnecessary, since a single surgical knot achieved the expected results.

Among the various factors that interfere with the increased resistance of the portal venous system, the main one is the rate of the vein constriction, but the thickness of the thread is also important. Wen et al. ${ }^{14}$ used various calibers of silk thread and opted for the 4-0 one, considering that with thinner threads the experimental model remained unstable and portal pressure low. Using very thin threads, these authors reported difficulty performing the knot, especially in small caliber veins, with approximate $1 \mathrm{~mm}$ of diameter. The strength of the knot must also be considered: if too tight, they can damage the vein with consequent thrombosis and if very loose, they may compromise the result of the experiment. Was consider essential to standardize the dissection of all tissues, isolating only the portal vein from the hepatic hilum structures; was used silk thread 6-0 for ophthalmic purposes, quite suitable for the delicacy required to adequately perform the experiment and was standardized, as best as possible, the tension of the knot, which was enough to adjust the vessel diameter to the catheter diameter and to the speed of the maneuver, in order to avoid prolonging complete obstruction of blood circulation. Was performed a single surgical knot and quickly removed the catheter to reestablish the flow through the constriction point of the vein. During the pilot project of this study was tried the polypropylene thread $5-0$, but the results were not satisfactory at all, with the death of all the animals, attributed to a possible injury to the endothelium vein by the thread and thrombosis with loss of the animal after the operation. The difficulty in making the knot with this type of thread must also be considered, once the knot adjustment to the catheter requires more tensile force to be applied by the surgeon. The technical difficulties represented by the delicacy of the dissected structures also justify the use of thin threads, which in this experiment affected the results.

The return of portal pressure to normal values in this experimental model was described in the late $1970 \mathrm{~s}^{11}$, but such controversy was been denied in recent studies, which confirmed the stability of this pressure near twice the normal amount for prolonged periods $s^{6,14}$, as well as the possibility to reverse this model if the constriction of the portal vein is undone, with the disappearance of the collateral circulation in most animals?.

It is considered that this experiment does not significantly compromise liver function ${ }^{2,14}$. Marques et al. ${ }^{7}$ showed that there were no changes in the histological aspect and the activity of enzymes indicative of liver damage, but there is a temporary reduction in the liver metabolism, without further hepatocellular damage.

\section{CONCLUSIONS}

The pre-hepatic portal hypertension in rats can be induced by a reduction of the vein caliber to $0.9 \mathrm{~mm}$ in diameter, regardless the vein initial diameter as well as the constriction rate to which this vessel was subjected.

\section{REFERENCES}

1. Al-Busafi SA, McNabb-Baltar J, Farag A, Hilzenrat N. Clinical manifestations of portal hypertension. Int J Hepatol 2012; 2012: $1-10$

2. Assef AJ, Vieira ACPO, Saito HCG, Lancellotte CLP, Szutan LA, De Cápua AJr. Modelo experimental de formação de varizes esofágicas por hipertensão portal esquistossomótica em hamsters. Rev Col Bras Cir 2005; 32: 209-13

3. Canty TG, Jauregizar E, Fernandez-Cruz L. Experimental portal hypertension in the rat. J Pediatr Surg 1980; 15: 819-26

4. Fabián GR, García GM, Fernández DB, Ravero MAA, Pérez AJ. Longterm portal hypertension in the rat by means of triple stenotic ligation of the portal vein. An Med Interna. 2000;17: 137-41

5. Ferri PM, Ferreira AR, Fagundes EDT, Liu SM, Albuquerque NN, Botelho FC, et al. Trombose de veia porta em crianças e adolescentes: revisão de literatura. Rev Med Minas Gerais 2011; 21(4 Supl 1): S36-S44 
6. Kountouras J, Billing BH, Scheuer PJ. Prolonged bile duct obstruction: a new experimental model for cirrhosis in the rat. Br J Exp Path 1984; 65: 305-11

7. Marques $C$, Mauriz JL, Simonetto $D$, Marroni CA, Tuñon MA González-Gallego J, et al. Glutamine prevents gastric oxidative stress in an animal model of portal hypertension gastropathy. Ann Hepatol 2011; 10: 531-9

8. Méndez-López $M$, Méndez $M$, Sánchez-Patán $F$, Casado I, Aller MA, López L, et al. Partial portal vein ligation plus thioacetamide: a method to obtain a new model of cirrhosis and chronic portal hypertension in the rat. J Gastrointest Surg 2007; 11: 187-94

9. Min YW, Bae SY, Gwak GY, Paik YH, Choi MS, Lee JH, et al. A clinical predictor of varices and portal hypertensive gastropathy in patients with chronic liver disease. Clin Mol Hepatol 2012; 18: 178-84

10. Morgan-Martins MI, Jaques SI, Hartmann RM, Marques CM, Marroni CA, Marroni NP. Protection of estrogen in portal hypertension gastropathy - an experimental model. Arq Gastroenterol 2011; 48: 211-6

11. Orda R, Ellis H. Self-established porto-caval and porto-pulmonary shuntsinmechanicallyinduced portal hypertension.Anexperimental study. Eur Surg Res 1978; 10: 172-83
12. Sikuler E, Kravetz D, Groszmann RJ. Evolution of portal hypertension and mechanisms involved in its maintenance in a rat model. Am J Physiol 1985; 248: G618-25

13. Silva AR, Kriguer-Júnior RJ, Serigiolle LC, Gomes HMP, Rodrigues $D A B$, Leme PLS. Aumento do volume do baço em modelo experimental de hipertensão portal pré-hepática em ratos. Arq Bras Cir Dig 2013;26(3):206-212.

14. Wen Z, Zhang JZ, Xia HM, Yang CX, Chen YJ. Stability of a rat model of prehepatic portal hypertension caused by partial ligation of the portal vein. World J Gastroenterol 2009; 15: 4049-54

15. Widman A, Oliveira IRS, Speranzini MB, Cerri GG, Saad WA, Gama-Rodrigues J. Hipertensão portal por esquistossomose mansônica hepatoesplênica: efeito da desconexão ázigo-portal com esplenectomia no diâmetro e na velocidade média de fluxo do sistema portal (estudo ultra-sonográfico com Doppler). Arq Gastroenterol 2001; 38: 19-23

16. Yokoyama Y, Baveja R, Sonin N, Clemens MG, Zhang JX. Hepatic neovascularizationafterpartial portalveinligation:novelmechanism of chronic regulation of blood flow. Am J Physiol Gastrointest Liver Physiol 2001; 280: G21-G31. 